\title{
PRE-SERVICE ENGLISH AS A FOREIGN LANGUAGE (EFL) TEACHERS' MOTIVES TO BECOME TEACHERS: A COMPARATIVE STUDY
}

\author{
Puput Arfiandhani \\ Muhammadiyah University of Yogyakarta \\ puput.arfiandhani@fpb.umy.ac.id \\ Ika Wahyuni Lestari \\ Muhammadiyah University of Yogyakarta \\ ikawahyuni_11@umy.ac.id
}

\begin{abstract}
To supply quality English as A Foreign Language (EFL) teachers, teachertraining programs which maintain its pre-service teachers' motives is important. The present study aims at comparing male and female pre-service teachers' motives in becoming EFL teachers. Within quantitative research paradigm, survey design was applied to collect the data from three private teacher-training institutions in Yogyakarta, Indonesia. Out of the total population of 231 pre-service teachers, 197 of them filled out the survey. 132 participants ( 96 females and 36 males) admitted that they wanted to be teachers. To find out whether there was any difference between male and female pre-service teachers' motives to become teachers, the T-test in SPSS 24 was used. The result indicated that Sig. (2-tailed) value (.612) was $<0.05$. This result indicated that there was no significant difference between male and female participants' motives. Additionally, the result of the descriptive statistics indicated that males' $(\mathrm{n}=36)$ level of motivation (2.94) was slightly higher than females' ( $\mathrm{n}=96$ ) motivation (2.90). Since no difference of level of motivation was shown, teacher-training programs may not always take into account gender differences when designing their programs.
\end{abstract}

Keywords: motives, pre-service teachers, male, female

\section{A. INTRODUCTION}

nglish as a Foreign Language (EFL) education has been growing fast in the last decades

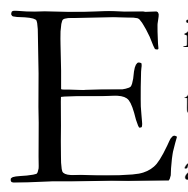

in Indonesia as a result of the demand of globalization. This phenomenon has also led to the growth of English teacher education programs in Indonesia. The programs aim at fulfilling the need for quality EFL teachers in the country. With the increasing need of English and the growing number of teacher education programs in Indonesia, many high school graduates are interested in taking teacher education programs in English language to become teachers. Undergraduate-level students who are enrolled in such trainings to become teachers are called as pre-service teachers.

One of the important elements that may contribute towards providing quality teachers is their motivation. As Dornyei (2011, p. 158) put it, "if a teacher is motivated to teach, there is a good chance that his or her students will be motivated to learn". Therefore, it is paramount to ensure the supply of motivated teachers that can deliver motivating teaching. Attracting high quality teachers has been a concern for policy makers over decades (Richardson and Watt, 2016, p. 275). It leads to the notion that teachers must also have motivation in teaching so that they can influence their students' learning positively. However, despite its potential importance, less attention is given 


\section{Volume 5, Number 02, December 2019}

to research on teacher motivation (Richardson and Watt, 2016, p. 276). In fact, understanding preservice teachers' motivation is important as the information can help designing pre-service teacher program that can maintain their motivation to become teachers.

One of the factors that may differ teacher motivational level, could be gender. In many parts of the world, female teachers have dominated teaching workforce $(>70 \%)$ (Richardson and Watt, 2016, p. 280). This data raised a question of whether there are any discrepancies between male and female before they become teachers. The present study aimed to investigate whether there is any difference between female and male pre-service teachers' motivation. In so doing, the level of motivation of each gender was investigated.

\section{B. LITERATURE REVIEW}

\section{Teacher Motivation}

Teacher motivation generally focuses on three areas: (1) issues regarding career choice that teachers choose, (2) complexities during the teaching process, and (3) factors influencing the relations of teachers and students. Dornyei (2001, p.165) pointed out that teacher motivation is not only to do with motivation to teach; it also has something to do with "motivation to be a teacher as a longlife career". It implies that motivation that teachers (or pre-service teachers) have might influence their career choice. Though indirectly teacher motivation might affect significantly on student motivation, studies examining the correlation between those two kinds on motivation have not got much exploration (Dornyei, 2001).

Teacher motivation has been widely studied in the field of general education and psychology in various contexts. The bulk of research on teacher motivation covered the area ranging from factors affecting motivation as well as motivational drives among teachers in various countries. Various kinds of methodologies have also been utilized to explore the topic of teacher motivation.

One of the insightful studies on teacher motivation was conducted by Kyriacou, Hultgreen and Stephens (1999). They investigated pre-service teachers' motivation to become a secondary school teacher in England and Norway. Some 105 pre-service teachers in Norway, and 112 in England filled out a questionnaire at the beginning of their teacher training program. Afterwards, 12 participants from each group were interviewed to gain a deeper understanding on what motivate them to become a secondary school teacher. The data analysis revealed that pre-service teachers' motivation to choose teaching in secondary school include enjoying the subject they would teach, liking to work with children, and the fact that teaching would enable them to use their subject.

Kyriacou's et al. (1999) findings were resonated in Manuel and Hughes' (2006) study. Their study on pre-service teachers' motivations for becoming teachers indicated that participants of the study chose to be teachers based on reasons that reflect personal aspirations. Through the questionnaire that they filled out, the participants' personal aspirations include making a difference in young people's lives; staying engaged with the subject area they were passionate about; and 
attaining personal fulfilment and meaning. Additionally, the study indicated that two thirds of the participants intended to teach for at least 10 years.

Studies on demotivating factors to become teachers shower various emerging aspects. Aydin's (2012) study on factors causing demotivation among EFL teachers in Turkey indicated that these factors include problems related to the teaching profession, curriculum, working conditions, students and their parents, colleagues and school administrators, and physical conditions. Demotivators such as teachers' physical conditions and working conditions corroborated Lestari's (2017) findings on demotivation among Indonesian EFL teachers. Muller, Alliata and Benninghoff's (2009) study on teacher retention in Swiss indicated that factors which affect teachers' motivation include job activities, working conditions and professional image. This is inline with Pelletier, Legault, and Se'guin-Le'vesque's (2002) findings that pressures that teachers perceive both from their colleagues, curriculum and performance standards as well as from their students could demotivate them. Additionally, within the context of Saudi Arabia, Shoaib's (2004) investigation on teachers' motivational factors revealed that government and institutions' policy also play a role in determining teachers' motivation.

\section{Motivations for Teaching}

Motivations level for teaching has been an important element to enhance students' language achievement. Papi and Abdollahzadeh (2012, p. 571) suggested that teachers' motivational teaching may contribute towards students' motivated behaviour in their language classes. Their motivated behaviour may consequently help them succeed. Bernaus and Gardner's (2008) path analysis result indicated that students' motivation of learning English has been indicated to be a strong predictor of their English language achievement.

Among many types of motivation, three types of motivation, i.e. intrinsic, extrinsic and altruistic, were frequently referred to (i.e. Muller, Alliata \& Benninghoff, 2009; Azman, 2013; Wong, Tang \& Cheng, 2014; Richardson and Watt, 2016; Hiver, Kim \& Kim, 2018). Azman's (2013) findings on EFL Malaysian teachers' motivation were drawn from his survey that was designed based on these three types of motivation. Hiver, Kim \& Kim (2013) assembled and reviewed studies on language teacher motivation and highlighted intrinsic and extrinsic motivation.

Altruistic motivation can be defined as factors related to teachers' morale and characters that aim a contributing to larger society. According to Hiver, Kim and Kim (2018, p. 4), altruistic motivation included "factors such as love, passion and dedication to learners, as well as a personal or moral commitment to contribute to society or reduce social inequality". In line with this, Richardson and Watt (2016, p. 280) noted that teachers who are altruistically motivated aspired that their teaching profession can be utilized to contribute to larger societies by shaping children's future, making social contribution and enhancing social equity.

Intrinsic motivation referred to motivation to teach which are related to teaching profession. Intrinsic motivation included internal motivation related to teachers' personal aspiration (Muller, 


\section{Volume 5, Number 02, December 2019}

Alliata, \& Benninghoff, 2009, p. 286). Hiver, Kim and Kim (2018, p.10) mentioned that intrinsic factors included "satisfaction of needs and interests, emotional payoffs, and the internal desire for personal growth, intellectual fulfillment and meaningfulness often found in educational settings".

On the other hand, extrinsic motivation included motivational drives to teach due to factors non-related to teaching profession. Wong, Tang and Cheng $(2014$, p. 82) exemplified that when teachers were motivate to teach due to income, prestige and long holidays that a teaching profession may offer, then, they could be extrinsically motivated. To conclude, extrinsic motivation included external factors surrounding teaching profession.

\section{Findings on Indonesian Teacher Motivation}

Within the context of Indonesia, not many studies has been conducted, both specifically about EFL teachers and teachers in general. Among the few is Marai's (2003) investigation on the double demotivation among Indonesian teaches. His findings indicated that teaching organizations should take into account teachers' motivation.

Another study on Indonesian teacher motivation was conducted by Mustafa and Othman (2010). They studied the effect of work motivation on teachers' work performance in Pekanbaru Senior High Schools, Indonesia. 327 senior high school teachers participated in this study; $40.2 \%$ of them were male and $59.8 \%$ of the participants were female. Employing a survey design study, the correlation between their motivation and performance were correlated. The results of the inferential statistical analysis revealed that there was a positive correlation between teachers' work performance and motivation. Additionally, further analysis on the difference between male and female teachers' motivation revealed that there was a significant different level of motivation between the two gender groups. Female teachers were found to be more motivated (Mean $=3.471$; Standard Deviation $=0.4709)$ in comparison to male teachers $($ Mean $=3.271$; Standard Deviation $=0.4773)$.

Arfiandhani's (2015) conducted a case study on Indonesian EFL teachers' motivational constructs. The findings of her study revealed that there were two emerging motives that drive participants of the study, two experienced EFL teachers, to become teachers. These motivations include their aspirations to motivate students and their English skills mastery of which can be put in use as an English teachers.

\section{METHOD}

\section{Design}

The present study employed quantitative research design. Quantitative design, specifically survey design, was used since the aim this research, which is to compare male and female preservice teachers' motivation, can be achieved through the design. A survey can be used to describe the nature of existing conditions to represent a wider target population (Cohen, Manion, \& Morrison, 2002, p. 256). 


\section{Population and Sampling}

The population of the study comprised of 231 sophomores in three private teacher-training institutions in Yogyakarta, Indonesia. According to Krejce and Morgan's (1970) in Sekaran (1992), with $5 \%$ confidence level, the minimum sampling was 145 . Among the total population that was targeted to participate in the study, only 197 of them volunteered to join this study. Out of 197 respondents, 65 of them admitted that they did not want to become teachers and only 132 of them mentioned that they aimed to become teachers. Among the total 132 respondents, 96 of them were female and 36 were male.

\section{Data Collection Method}

To collect the data, a 4-Likert scale questionnaire consisting of 24 items was employed. The questionnaire was adapted from Azman (2013). Three changes were done to suit Indonesian context. The first change was to delete one item of the questionnaire (statement: Influenced by husband/wife) due to the irrelevancy of the context in which most participants were unmarried. The second change was to change the statement of "Helping government achieve the Vision 2020" into "Help the government achieve the vision "Indonesia Emas" 2045". The third change was to translate all items into Indonesian language he ease participants with filling out the questionnaire. As developed by Azman (2013), the items focused on three types of motivation, namely intrinsic, extrinsic and altruistic motivation. The distribution of the questionnaire items were as followed.

Table 1. The Item Distribution of the Questionnaire

\begin{tabular}{|c|c|c|c|}
\hline No & Types of Motivation & \multicolumn{1}{|c|}{ Items } & No. of the Items \\
\hline 1. & Intrinsic & $4,5,7,12,14,15,24$ & 7 \\
\hline 2. & Extrinsic & $1,2,3,8,9,16,17,18,20,23$ & 10 \\
\hline 3. & Altruistic & $6,10,11,13,19,21,22$ & 7 \\
\hline \multicolumn{2}{|r|}{ Total } \\
\hline
\end{tabular}

The instrument used in the data collecting procedure was a survey an adopted version of Azman (2011). The questionnaire consisted of 24 items (originally 25) and explored pre-service teachers' career motivation. To ensure the validity of the questionnaire, two teaching staff with doctorate degree in researchers' department was asked to give their expert judgment. Their feedback was then taken into account in revising the readability of the questionnaire.

\section{Data Analysis}

To find out male and female pre-service teachers' motivation, descriptive statistical analysis using SPSS 24 was conducted. The mean score of the motivation level was then categorized into five categories: very low $(1-1,6)$, low $(1,7-2,2)$, moderate $(2,3-2,8)$, high $(2,9-3,4)$, and very high $(3,5-4)$. Additionally, the mean score of each component of the motivation, i.e. extrinsic, intrinsic and altruistic, was also calculated and categorized. 
To find out if there was any difference between male and female pre-service teachers' motivation, T-test was used. The results of the questionnaire were statistically analyzed using SPSS 24. The result of statistical analysis shown that the data were homogenous, as indicated by Levene's test for quality of variances $(\mathrm{F}=6.965)$. Therefore, pooled T-test was applied.

\section{RESULTS AND DISCUSSION}

The present study aims at comparing male and female pre-service teachers' motivation to become teachers to find out if there is difference between male and female pre-service teachers' motivation. Understanding teachers' motivation is indeed important as teachers play a key role on affecting the motivational quality of learning process (Dornyei \& Ushioda, 2011, p. 28). To find out the level of motivation of male and female participants, the results of descriptive analysis was presented. In addition, to answer the research question on the different level of motivation, T-test was employed.

\section{Male Pre-Service Teachers' Motives to Become Teachers}

The results of the survey of male pre-service teachers' motives to become teachers indicated that that the mean score of male pre-service teachers' ( $N=36)$ motives to become teachers is 2.94 with standard deviation of 0.264 . This score indicated that they have high motivation to become teachers.

Table 2. Descriptive Statistical Analysis of Male and Female Motivation

\begin{tabular}{|l|r|r|r|r|r|}
\hline \multicolumn{7}{|c|}{ Group Statistics } \\
\hline & Gender & $\mathrm{N}$ & Mean & \multicolumn{1}{c|}{$\begin{array}{c}\text { Std. } \\
\text { Deviation }\end{array}$} & $\begin{array}{c}\text { Std. Error } \\
\text { Mean }\end{array}$ \\
\hline Motivation & Fem & 96 & 2.9075 & .37589 & .03836 \\
& ale & & & & .26407 \\
\cline { 2 - 7 } & Male & 36 & 2.9422 & .04401 \\
\hline
\end{tabular}

The type of motivation which has the highest mean is altruistic motivation with the mean score of 3.43. The second highest score was of intrinsic motivation with the mean score of 3.17. The lowest mean score of motivation was of extrinsic motivation (mean $=2.44$ ). Dinham and Scott's study in Hettiarachchi (2013) corroborated the result. Their survey study which involved teachers from Australia, New Zealand and England reported that teachers are often intrinsically motivated by matters related to teaching.

The mean score of altruistic motivation was 3.43. This number indicated participants' high altruistic motivation to become teachers. The highest score of the altruistic motivation was for item 11 ("perform a service of value") with the mean score of 3.83 which could be categorized to be very high. The lowest score was 2.97 for item 21 (“a respected job”). 
The mean score of extrinsic motivation of male pre-service teachers' motivation is 2.44 which can be categorized as moderate. The highest mean score is for item 20 with the mean score of 3.28 which can be categorized to be very high. The choice of this item represented that participants admitted that they chose to be teachers because becoming a teacher offers opportunities for further studies. Additionally, the lowest score was for item 17 ("no other choices") with the mean score of 1.58 , which meant to be very low.

Table 3. Male Pre-Service Teachers' Motives to Become Teachers

\begin{tabular}{|c|c|c|c|c|}
\hline \multirow{2}{*}{$\begin{array}{l}\text { Type of } \\
\text { Motivation }\end{array}$} & \multirow[t]{2}{*}{$\begin{array}{l}\text { Item } \\
\text { No. }\end{array}$} & \multirow[t]{2}{*}{ Motives } & \multirow{2}{*}{$\begin{array}{c}\begin{array}{c}\text { Per } \\
\text { Item }\end{array} \\
\text { Mean }\end{array}$} & \multirow{2}{*}{$\begin{array}{c}\text { Per } \\
\text { Type } \\
\text { Mean }\end{array}$} \\
\hline & & & & \\
\hline \multirow{10}{*}{ Extrinsic } & 1 & Influenced by parents & 2.22 & \multirow{10}{*}{2.44} \\
\hline & 2 & Influenced by former teacher & 3.03 & \\
\hline & 3 & Influenced by friends & 1.81 & \\
\hline & 8 & A secure job & 2.47 & \\
\hline & 9 & A reasonable workload & 2.39 & \\
\hline & 16 & $\begin{array}{l}\text { A job that is easily compatible with } \\
\text { parenthood }\end{array}$ & 3.08 & \\
\hline & 17 & No other choices & 1.58 & \\
\hline & 18 & A lot of free time/long vacation & 2.19 & \\
\hline & 20 & Opportunities for further studies & 3.28 & \\
\hline & 23 & Good salary & 2.33 & \\
\hline \multirow{7}{*}{ Intrinsic } & 4 & It has always been my ambition & 2.61 & \multirow{7}{*}{3.17} \\
\hline & 5 & Suited to my potentials and ability & 3.08 & \\
\hline & 7 & $\begin{array}{l}\text { Appropriate to my academic } \\
\text { qualification }\end{array}$ & 3.08 & \\
\hline & 12 & A job that I find enjoyable & 3.28 & \\
\hline & 14 & $\begin{array}{l}\text { Career that provides intellectual } \\
\text { challenges (not boring) }\end{array}$ & 3.50 & \\
\hline & 15 & $\begin{array}{l}\text { I can learn a lot more about } \\
\text { children }\end{array}$ & 3.03 & \\
\hline & 24 & $\begin{array}{l}\text { I want to become a professional } \\
\text { teacher }\end{array}$ & 3.64 & \\
\hline \multirow{7}{*}{ Altruistic } & 6 & Love of children & 2.97 & \multirow{7}{*}{3.43} \\
\hline & 10 & Contribute to society & 3.72 & \\
\hline & 11 & Perform a service of moral value & 3.83 & \\
\hline & 13 & Love for teaching & 3.28 & \\
\hline & 19 & $\begin{array}{l}\text { Help government achieve vision } \\
2045 \text { (Indonesia Emas) }\end{array}$ & 3.53 & \\
\hline & 21 & A respected job & 2.97 & \\
\hline & 22 & $\begin{array}{l}\text { Teach and mould young } \\
\text { generation }\end{array}$ & 3.69 & \\
\hline
\end{tabular}

The mean score of intrinsic motivation was 3.17. This number represented participants' high intrinsic motivation to become teachers. This result is in accordance with Ghenghesh' (2013) findings. His qualitative study about EFL teachers in Egypt revealed that teachers' strongest motivational drive was intrinsic motivation such as teacher profession tended to have good relationship. The highest score was 3.64 for item 24 ("I want to become a professional teacher") 
which can be categorized to be very high. In addition, the lowest score was 2.61 for item 4 ("It has always been my ambition") which can be categorized to be moderate.

\section{Female Pre-Service Teachers' Motives to Become Teachers}

Almost similar with male's result, the results of the survey of female pre-service teachers' motives to become teachers indicated that that the mean score of female pre-service teachers' $(\mathrm{N}=$ 96) motives to become teachers is 2.91 with standard deviation of 0.261 (Table 5). This score indicated that they have high motivation to become teachers.

The comparison of the mean score among three types of teacher motivation i.e. extrinsic, intrinsic and altruistic, yielded similar result of that of male's. The highest mean score of female teachers' motivation was from their altruistic motivation (mean=3,34). The second highest was their intrinsic motivation and the lowest one was their extrinsic motivation.

The result of descriptive statistical analysis indicated that the mean score for extrinsic motivation among female pre-service teachers' motivation was 2.44 , which could be categorized to be moderate. The aspect within extrinsic motivation that earned the highest score was item 20 ("Opportunities for further study") with the mean score of 3.34 which could be categorized to be high. Meanwhile, the lowest score was for item 17 ("No other choices") with the mean score of 1.63 which can be categorized as low.

The mean score of intrinsic motivation was 3.13. This number represented participants' high intrinsic motivation to become teachers. Similar with the highest score for male's intrinsic motivation, the highest score was 3.48 for item 24 ("I want to become a professional teacher") which can be categorized to be high. In addition, the lowest score was 2.54 for item 4 ("It has always been my ambition") which can be categorized to be moderate.

The result of the descriptive statistical analysis of altruistic motivation indicated that female pre-service teachers' altruistic motivation was categorized to be high, as indicated by their mean score of 3.34. The highest score was for item 11 ("perform a service of moral value") with the mean score of 3.76 that can be categorized to be very high. The lowest score was for item 21 ("a respected job”) with the mean score of 2.91 that can be categorized to be high.

Table 4. Female Pre-Service Teachers' Motives to Become Teachers

\begin{tabular}{|c|c|c|c|c|}
\hline \multirow{2}{*}{$\begin{array}{c}\text { Type of } \\
\text { Motivation }\end{array}$} & \multirow{2}{*}{$\begin{array}{l}\text { Item } \\
\text { No. }\end{array}$} & \multirow{2}{*}{ Motives } & Per Item & Per Type \\
\hline & & & Mean & Mean \\
\hline \multirow{8}{*}{ Extrinsic } & 1 & Influenced by parents & 2.35 & \multirow{8}{*}{2.44} \\
\hline & 2 & Influenced by former teacher & 2.88 & \\
\hline & 3 & Influenced by friends & 1.48 & \\
\hline & 8 & A secure job & 2.74 & \\
\hline & 9 & A reasonable workload & 2.52 & \\
\hline & 16 & $\begin{array}{l}\text { A job that is easily compatible with } \\
\text { parenthood }\end{array}$ & 3.11 & \\
\hline & 17 & No other choices & 1.63 & \\
\hline & 18 & A lot of free time/long vacation & 2.17 & \\
\hline
\end{tabular}


Ika Wahyuni Lestari, Puput Arfiandhani, Pre-Service English....

\begin{tabular}{|c|c|c|c|c|}
\hline & 20 & Opportunities for further studies & 3.34 & \\
\hline & 23 & Good salary & 2.21 & \\
\hline \multirow{7}{*}{ Intrinsic } & 4 & It has always been my ambition & 2.54 & \multirow{7}{*}{3.13} \\
\hline & 5 & Suited to my potentials and ability & 3.00 & \\
\hline & 7 & $\begin{array}{l}\text { Appropriate to my academic } \\
\text { qualification }\end{array}$ & 3.21 & \\
\hline & 12 & A job that I find enjoyable & 3.46 & \\
\hline & 14 & $\begin{array}{l}\text { Career that provides intellectual } \\
\text { challenges (not boring) }\end{array}$ & 3.50 & \\
\hline & 15 & I can learn a lot more about children & 3.26 & \\
\hline & 24 & $\begin{array}{l}\text { I want to become a professional } \\
\text { teacher }\end{array}$ & 3.48 & \\
\hline \multirow{7}{*}{ Altruistic } & 6 & Love of children & 3.04 & \multirow{7}{*}{3.34} \\
\hline & 10 & Contribute to society & 3.64 & \\
\hline & 11 & Perform a service of moral value & 3.76 & \\
\hline & 13 & Love for teaching & 3.09 & \\
\hline & 19 & Help government achieve vision 2045 & 3.46 & \\
\hline & 21 & A respected job & 2.91 & \\
\hline & 22 & Teach and mould young generation & 3.52 & \\
\hline
\end{tabular}

\section{A Comparison between Male and Female Pre-Service Teachers' Motives}

To find out whether there was any difference between male and female pre-service teachers' motives to become teachers, T-test in SPSS 24 was used. The result indicated that the Sig. (2-tailed) value $(.612)$ was $<0.05$. This result showed that there was no difference between male and female pre-service teachers' motives to become teachers. Kocabs' (2009) findings on Turkish in-service teachers' motivation corroborated this finding, that motivation of both gender tend to be similar.

Table 5. Independent Samples Test of Male and Female Pre-Service Teachers' Motivation

\begin{tabular}{|c|c|c|c|c|c|c|c|c|c|c|}
\hline \multicolumn{11}{|c|}{ Independent Samples Test } \\
\hline & & \multicolumn{2}{|c|}{$\begin{array}{c}\text { Levene's Test } \\
\text { for Equality of } \\
\text { Variances }\end{array}$} & \multicolumn{7}{|c|}{ t-test for Equality of Means } \\
\hline & & \multirow[b]{2}{*}{$\mathrm{F}$} & \multirow[b]{2}{*}{ Sig. } & \multirow[b]{2}{*}{$\mathrm{t}$} & \multirow[b]{2}{*}{ df } & \multirow{2}{*}{$\begin{array}{l}\text { Sig. }(2- \\
\text { tailed) }\end{array}$} & \multirow{2}{*}{$\begin{array}{c}\text { Mean } \\
\text { Differen } \\
\text { ce }\end{array}$} & \multirow{2}{*}{$\begin{array}{c}\text { Std. } \\
\text { Error } \\
\text { Differen } \\
\text { ce }\end{array}$} & \multicolumn{2}{|c|}{$\begin{array}{c}95 \% \text { Confidence Interval } \\
\text { of the Difference }\end{array}$} \\
\hline & & & & & & & & & Lower & Upper \\
\hline \multirow[t]{2}{*}{$\begin{array}{l}\text { Motiva } \\
\text { tion }\end{array}$} & $\begin{array}{l}\text { Equal } \\
\text { variances } \\
\text { assumed }\end{array}$ & 6.965 & .009 & -.509 & 130 & .612 & -.03472 & .06827 & -.16979 & .10034 \\
\hline & $\begin{array}{l}\text { Equal } \\
\text { variances not } \\
\text { assumed }\end{array}$ & & & -.595 & $\begin{array}{r}89.38 \\
3\end{array}$ & .554 & -.03472 & .05838 & -.15072 & .08128 \\
\hline
\end{tabular}


Volume 5, Number 02, December 2019

The result of the descriptive statistical analysis using SPSS 24 indicated that the mean score of male and female motivation was almost similar. The mean score of female participants $(\mathrm{N}=96)$ was 2.91 with standard deviation of 0.37 . This score indicated that female participants' motivation level was high. The mean score of male participants $(\mathrm{N}=36)$ was 2.94 with standard deviation of 0.26. This score indicated that male participants' motivation level was high. In addition, both male and female pre-service teachers' highest motivational drive was altruistic motivation which then followed by intrinsic motivation. Extrinsic motivation was found to be the motivation type with the lowest mean score of both gender groups. The fact that altruistic and intrinsic motivational drive resonated Wong, Tang and Cheng's (2014) result of study. Their findings indicated that altruistic and intrinsic motivation were found to be two most important motivational drive to be teachers among EFL teachers in Hongkong.

Table 6. Descriptive Statistical Analysis of Male and Female Motivation

\begin{tabular}{|l|l|r|r|r|r|}
\hline \multicolumn{7}{|c|}{ Group Statistics } \\
\hline & Gender & $\mathrm{N}$ & \multicolumn{1}{|c|}{ Mean } & Std. Deviation & Std. Error Mean \\
\hline Motivation & Female & 96 & 2.9075 & .37589 & .03836 \\
\cline { 2 - 6 } & Male & 36 & 2.9422 & .26407 & .04401 \\
\hline
\end{tabular}

As an effort to ensure the supply of quality teachers, designing teacher education program that contributes towards fulfilling the need is essential. Teacher motivations contribute towards building teachers' ability to nurture intellectual curiosity and drive to succeed among students (Hiver, Kim and Kim, 2018, p.10). Understanding teachers' motivation is important as it may shed light on who will enter the teaching profession, stay in it and the way they go about their teaching (Muiller, Alliata, \& Benninghoff, 2009).

\section{E. CONCLUSION}

The result of the study indicates that there was no difference between male and female preservice teachers' motivation based on the result of the T-test. Additionally, the result of the descriptive statistical analysis indicated that the mean score between female $(\mathrm{N}=96)$ and male $(\mathrm{N}=36)$ pre-service teachers' motivation was relatively the same. The mean score for female was 2.90 with the standard deviation of 0.38 and for male was 2.94 with the standard deviation of 0.26 . To sum up, there was no difference between male and female pre-service teachers' motivation in three teacher-training institutions in Yogyakarta.

Since there was no different motives betwee male and female pre-service teachers, teachertraining institutions may not always take into account these gender differences when designing 
Ika Wahyuni Lestari, Puput Arfiandhani, Pre-Service English....

their programs. The institutions may design programs which motivate their students to become quality and professional teachers. However, since no different aspects of motivation were indicated in the results of the study, the motivating programs aiming for male and female can be designed to be the same.

Interestingly, in both gender groups, extrinsic motivation was indicated to be the lowest aspect of motivational drives and all are categorized to be moderate. Additionally, both male and female's altruistic and intrinsic motivation were reported to be high. It could be concluded that both male and female tend to be both motivated intrinsically and altruistically.

Meanwhile, further studies on various topics on the area of teacher motivation may be conducted to understand more on motivating practices. These studies may benefit designing motivating teacher-training programs that could sustain and maintain pre-service teachers' motivation. Creating such programs may lead to programs that can supply professional and quality teachers in the future.

\section{REFERENCES}

Arfiandhani, P. (2015). A case study of L2 teachers' possible selves: What motivates them and how they respond to educational reforms, an Indonesian context. Unpublished dissertateion, University of Nottingham.

Aydin, S. (2012). Factors causing demotivation in EFL teaching process: A case study. The qualitative report, 17(51), 1.

Bernaus, M., \& Gardner, R. C. (2008). Teacher motivation strategies, student perceptions, student motivation, and English achievement. The Modern Language Journal, 92(3), 387-401.

Cohen, L., Manion, L., \& Morrison, K. (2002). Research Methods in Education. Routledge: London.

Creswell, J. W. (2012). Educational research: planning, conducting and evaluating quantitative and qualitative research (fourth edition). Boston: Pearson Education

Dinham, S. \& Scott, C. (2000). Moving into the third, outer domain of teacher satisfaction. Journal of Educational Administration, 38(4), 379-396.

Dornyei, Z. (2001). New themes and approaches in second language motivation research. Annual Review of Applied Linguistics, 21: 43-59.

Dornyei, Z. and Ushioda, E. (2011). Teaching and researching motivation: Second edition. Harlow: Pearson Education Limited 
Volume 5, Number 02, December 2019

Ghenghesh, P. (2013). Job Satisfaction and Motivation-What Makes Teachers Tick?. Journal of Education, Society and Behavioural Science, 456-466.

Hettiarachchi, S. (2013). English language teacher motivation in Sri Lankan public schools. Journal of Language Teaching and Research, 4(1): 1-11

Hiver, P., Kim, T.-Y., \& Kim, Y. (2018). Language teacher motivation. In S. Mercer \& A. Kostoulas (Eds.), Language Teacher Psychology (pp. 18-33). Bristol, England: Multilingual Matters.

Kocabas, I. (2009). The effects of sources of motivation on teachers' motivation levels. Education, 129(4), 724-734.

Kyriacou, C., Hultgren, Å., \& Stephens, P. (1999). Student teachers' motivation to become a secondary school teacher in England and Norway. Teacher Development, 3(3), 373-381.

Lestari, I. W. (2017). Demotivating Factors among Indonesian EFL Teachers. Journal of Foreign Languange Teaching and Learning, 2(1).

Manuel, J. \& Hughes, J. (2006) 'It has always been my dream': exploring pre-service teachers' motivations for choosing to teach, Teacher Development, 10(1), 5-24.

Marai, L. (2003). Double de-motivation and negative social affect among teachers in Indonesia. South Pacific Journal of Psychology, 14, 1-7.

Müller, K., Alliata, R., \& Benninghoff, F. (2009). Attracting and retaining teachers: A question of motivation. Educational Management Administration \& Leadership, 37(5), 574-599.

Mustafa, M. N., \& Othman, N. (2010). The effect of work motivation on teacher's work performance in Pekanbaru senior high schools, Riau Province, Indonesia. Sosiohumanika, 3(2).

Papi, M., \& Abdollahzadeh, E. (2012). Teacher motivational practice, student motivation, and possible L2 selves: An examination in the Iranian EFL context. Language Learning, 62(2), 571-594.

Pelletier, L. G., Séguin-Lévesque, C., \& Legault, L. (2002). Pressure from above and pressure from below as determinants of teachers' motivation and teaching behaviors. Journal of Educational Psychology, 94(1), 186.

Shoaib, A. (2004). The motivation of teachers of English as a second language in Saudi Arabia. Unpublished doctoral dissertation, University of Nottingham, Nottingham.

Wong, A. K., Tang, S. Y., \& Cheng, M. M. (2014). Teaching motivations in Hong Kong: Who will choose teaching as a fallback career in a stringent job market?. Teaching and teacher education, 41, 81-91. 